\title{
Hepatitis C virus genotype frequency in Isfahan province of Iran: a descriptive cross-sectional study
}

Sayyed H Zarkesh-Esfahani ${ }^{1,2^{*}}$, Mohammad T Kardi ${ }^{3}$, Masoud Edalati ${ }^{4}$

\begin{abstract}
Background: Hepatitis $C$ is an infectious disease affecting the liver, caused by the hepatitis $C$ virus $(H C V)$. The hepatitis C virus is a small, enveloped, single-stranded, positive sense RNA virus with a large genetic heterogeneity. Isolates have been classified into at least eleven major genotypes, based on a nucleotide sequence divergence of 30-35\%. Genotypes 1, 2 and 3 circulate around the world, while other genotypes are mainly restricted to determined geographical areas. Genotype determination of HCV is clinically valuable as it provides important information which can be used to determine the type and duration of therapy and to predict the outcome of the disease.
\end{abstract}

Results: Plasma samples were collected from ninety seven HCV RNA positive patients admitted to two large medical laboratory centers in Isfahan province (Iran) from the years 2007 to 2009. Samples from patients were subjected to HCV genotype determination using a PCR based genotyping kit. The frequency of HCV genotypes was determined as follows: genotype 3a (61.2\%), genotype 1a (29.5\%), genotype $1 \mathrm{~b}(5.1 \%)$, genotype $2(2 \%)$ and mixed genotypes of $1 \mathrm{a}+3 \mathrm{a}$ (2\%).

Conclusion: Genotype $3 \mathrm{a}$ is the most frequent followed by the genotype $1 \mathrm{a}$, genotype $1 \mathrm{~b}$ and genotype 2 in Isfahan province, Iran.

\section{Background}

Hepatitis C virus (HCV) is a small enveloped virus first isolated in 1989 and belongs to the family of flaviviridae [1]. Its genome is composed of a positive-sense, singlestranded RNA encoding a polyprotein comprising structural (core and envelope glycoproteins E1 and E2) and non-structural (NS2, NS3a/b, NS4a/b and NS5a/b) proteins. Acute HCV infection is often asymptomatic and approximately $70 \%$ of all cases progress to chronic hepatitis. This may lead to progressive liver disease, cirrhosis, liver failure and hepatocellular carcinoma within 20 to 30 years. Factors associated with disease progression following infection include the viral genotype, the patient's alcohol consumption and viral load [2]. Determination of the HCV genotype provides clinically important information that can be used to direct the type and duration of anti-viral therapy and to predict the

\footnotetext{
* Correspondence: s.h.zarkesh@sheffield.ac.uk

'Department of Biology, Faculty of Sciences, University of Isfahan, Isfahan, 81746-73695, IR, IRAN
}

likelihood of sustained HCV clearance after therapy $[3,4]$. Patients with HCV genotype 1 may benefit from a longer course of therapy and genotypes 2 and 3 are more likely to respond to a combination of interferon and Ribavirin therapy [5]. Most genotyping methods include a first step of reverse transcription (RT) of viral RNA and polymerase chain reaction (PCR) amplification. The conserved 5' non-coding region of the $\mathrm{HCV}$ genome has been used as a target for a number of diagnostic assays. This region can be characterized by probe hybridization or by variation in restriction patterns [6,7].

Global patterns for the distribution of different $\mathrm{HCV}$ genotypes are as follows:

1a is mostly found in North and South America, also common in Australia.

$1 \mathrm{~b}$ is mostly found in Europe and Asia.

$2 \mathrm{a}$ is the most common genotype 2 in Japan and China.

$2 \mathrm{~b}$ is the most common genotype 2 in the US and north Europe. 
$2 \mathrm{c}$ is the most common genotype 2 in western and southern Europe.

3a is highly prevalent in Australia (40\% of cases) and south Asia.

4a is highly prevalent in Egypt.

4c is highly prevalent in central Africa.

$5 \mathrm{a}$ is highly prevalent only in south Africa.

6a is restricted to Hong Kong, Macau and Vietnam.

$7 \mathrm{a}$ and $7 \mathrm{~b}$ are common in Thailand.

$8 \mathrm{a}, 8 \mathrm{~b}$ and $9 \mathrm{a}$ are prevalent in Vietnam.

$10 \mathrm{a}$ and 11a are found in Indonesia [8].

The aim of the present study is to determine the frequency of $\mathrm{HCV}$ genotypes in Isfahan province, Iran.

\section{Results}

Patients were referred to two medical centers in Isfahan by specialists and were suspected of hepatitis. They were screened primarily for anti HCV antibodies. Samples from one hundred and forty-six patients who were positive for anti HCV antibodies were subjected to conventional RT-PCR for detection of HCV RNA (Figure 1). Ninety seven patients were identified positive for $\mathrm{HCV}$ nucleic acid. The mean age of the HCV nucleic acid positive patients was 35 years (16-78 years). Ninety-five subjects $(97.9 \%)$ were male and two $(2.1 \%)$ were female. Samples from these HCV RNA positive patients were used in a genotype determining method based on PCR technique. In this method different genotypes generate PCR products which are different in sizes (Figure 2). Genotypes of $\mathrm{HCV}$ were determined in all ninety seven patients. Genotypes 1a, 1b, 2 and 3a were detected and in some cases mixed infections with more than one genotype $(1 \mathrm{a}+3 \mathrm{a})$ were revealed. Predominant genotypes were genotype $3 \mathrm{a}(61.2 \%), 1 \mathrm{a}(29.5 \%)$ and $1 \mathrm{~b}(5.1 \%)$. A less frequent genotype was genotype $2(2 \%)$. There were also two cases with mixed genotype infection of $1 \mathrm{a}$ and 3a (2\%) (Figure 3).

\section{Discussion}

Hepatitis $C$ infection may lead to a substantial health and economic burden over the next 10 to 20 years. From a public health perspective, the implementation of molecular tests as an integral part of the diagnostic and therapeutic management of infections with HCV should be imperative. Due to different treatment schedules between genotype 1 (48 weeks) and genotypes 2 and 3 (24 weeks), genotype distribution has a significant influence on the total costs and morbidity of HCV treatment. Nucleotide sequence analysis may be regarded as the gold standard for the identification of different $\mathrm{HCV}$ genotypes and subtypes, but it is generally believed to be impractical for routine clinical laboratory settings. Several alternative HCV genotyping procedures have therefore been suggested which are usually based on the

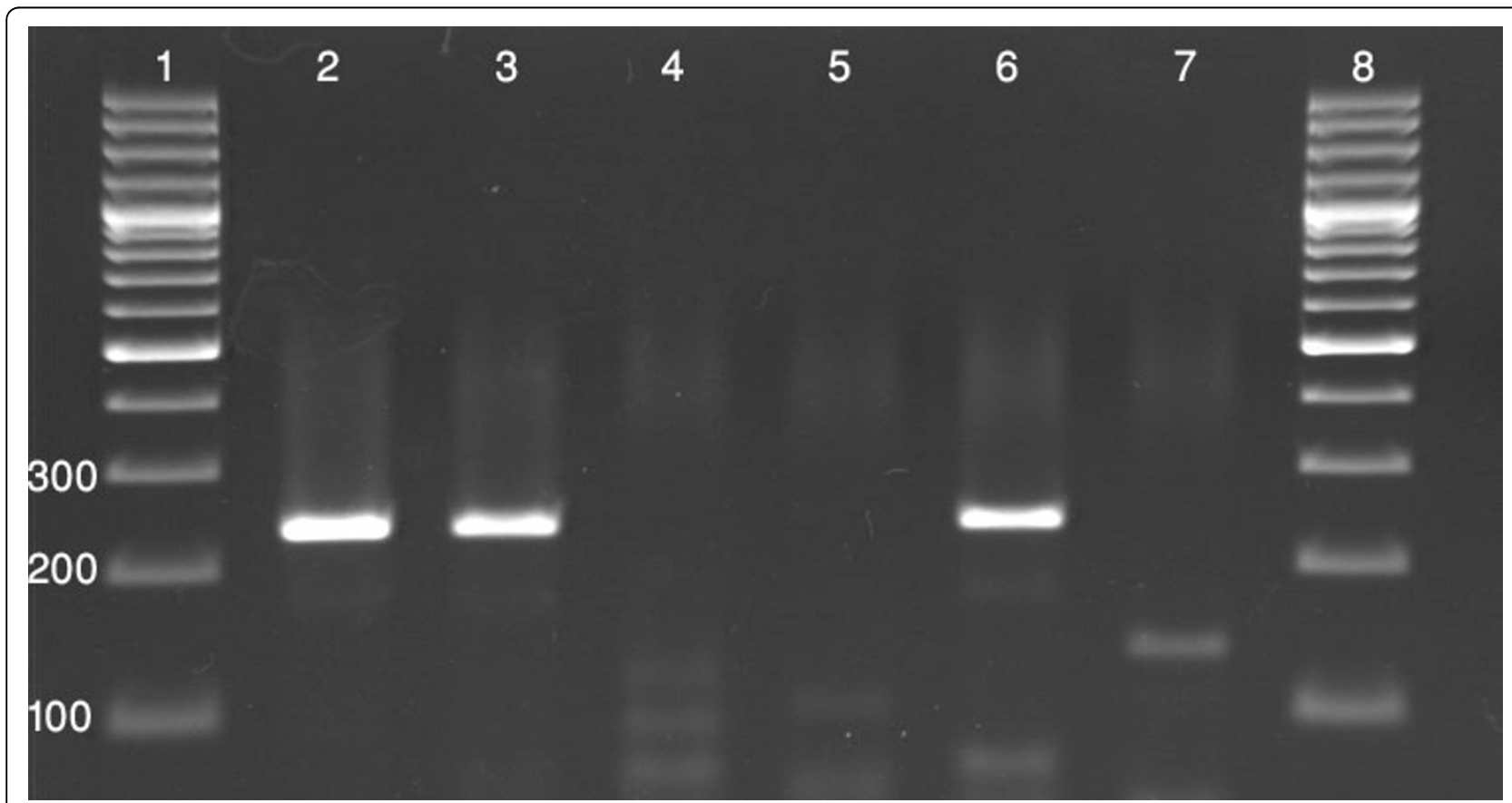

Figure $1 \mathrm{~A}$ representative agarose gel electrophoresis of PCR products for the detection of HCV nucleic acid in plasma of patients positive for anti HCV antibodies. Plasma samples from anti-HCV antibody positive patients were subjected to RT-PCR using general primers which are able to detect HCV nucleic acid by generating a 227 bp product. Lanes 1 and 8: 100 bp DNA size marker, lane 2: positive control, lanes 3 and 6: patients positive for HCV nucleic acid, lane 4: negative control, lanes 5 and 7: patients negative for HCV nucleic acid. 


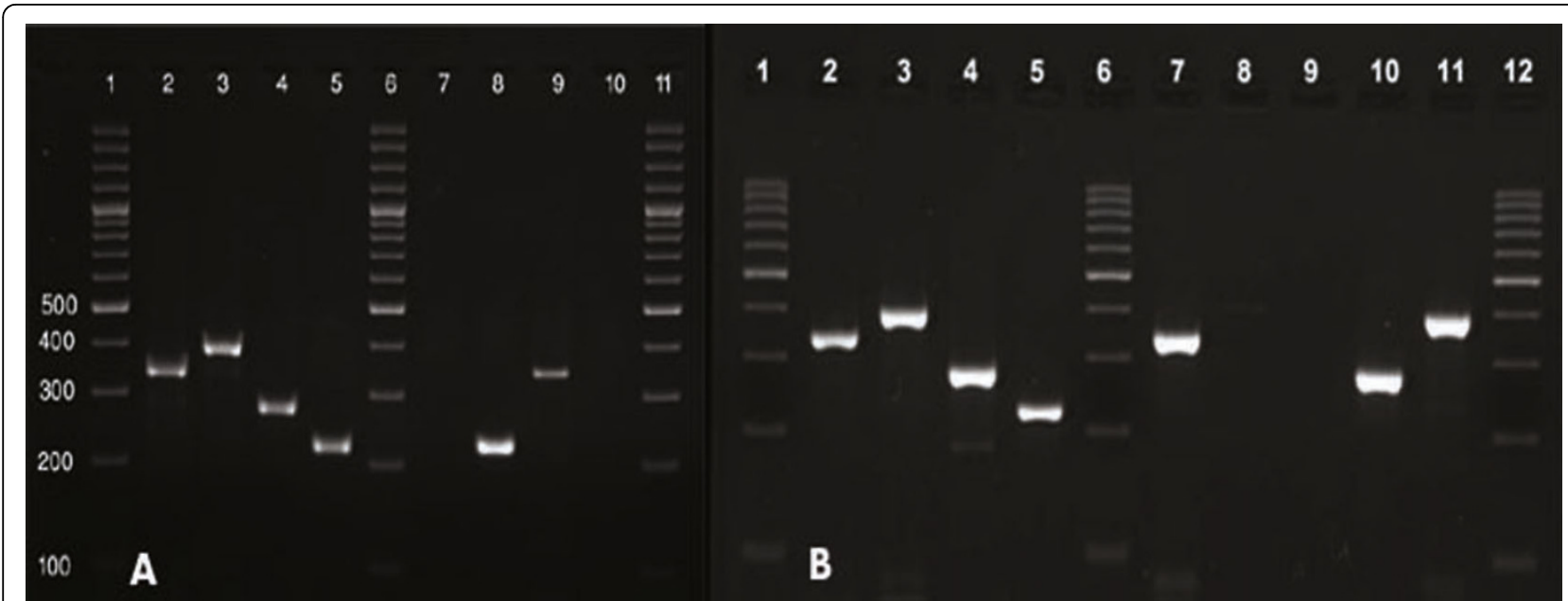

Figure 2 Two representative agarose gels of PCR products demonstrating different HCV genotypes. Plasma samples from patients positive for HCV nucleic acid were subjected to genotype determination using a specific RT-PCR kit which produces different size PCR products related to different genotypes. A) Lanes 1, 6 and 11: 100 bp DNA size marker, lane 2: positive control for genotype 1a (338 bp), lane 3: positive control for genotype $1 \mathrm{~b}$ (395 bp), lane 4: positive control for genotype 2 (286 bp), lane 5: positive control for genotype $3 a$ (227 bp), lanes 7 and 8: two sets of PCR amplifications for one patient resulting in genotype 3a, lanes 9 and 10: two sets of PCR amplifications for another patient resulting in genotype 1a. B) Lanes 1, 6 and 12: 100 bp DNA size marker, lane 2: positive control for genotype 1a (338 bp), lane 3: positive control for genotype $1 \mathrm{~b}$ (395 bp), lane 4: positive control for genotype 2 (286 bp), lane 5: positive control for genotype 3a (227 bp), lanes 7 and 8: two sets of PCR amplifications for one patient resulting in genotype 1a, lane 9: empty well, lane 10: patient positive for genotype 2, lane 11: patients positive for genotype $1 \mathrm{~b}$.

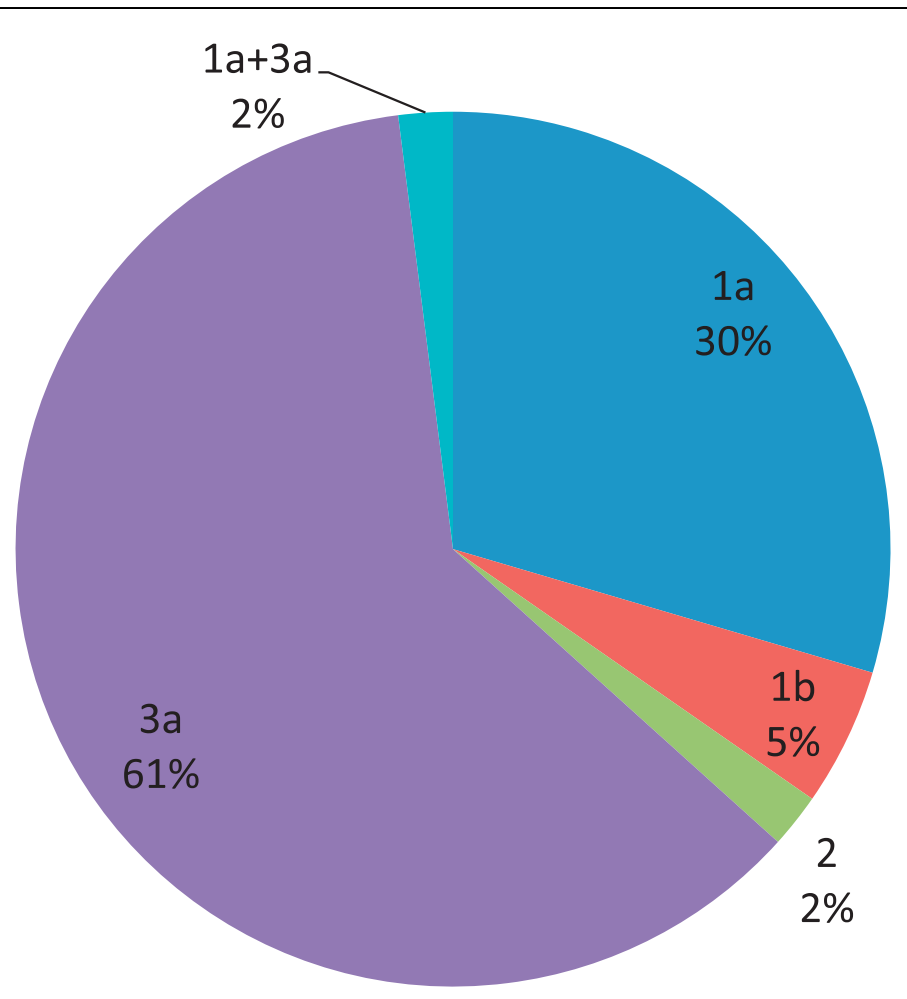

Figure 3 Frequency of different HCV genotypes in Isfahan province of Iran. HCV genotypes were determined in ninety-seven HCV RNA positive patients admitted to two large medical centers between 2007 and 2009 in Isfahan province, Iran. Predominant genotypes were: 3a (61.2\%), $1 \mathrm{a}(29.5 \%)$ and $1 \mathrm{~b}(5.1 \%)$. Less frequent was genotype 2 (2\%). Mixed genotype infection of $1 \mathrm{a}$ and $3 \mathrm{a}$ was also observed in two cases (2\%). 
analysis of PCR products by hybridization with genotype-specific probes or restriction length polymorphism analysis. In a routine diagnostic virology laboratory, simpler, faster and less expensive methods are required. In this study, we used a commercial RT-PCR genotyping kit which is able to determine common HCV genotypes in less than a few hours. This investigation was performed in Isfahan province, one of the most populated provinces, of Iran. HCV genotype 3a was found to be the most prevalent $(61.2 \%)$, followed by genotype $1 \mathrm{a}$ (29.5\%), 1b (5.1\%), genotype $2(2 \%)$ and mixed genotypes of 1a plus 3a (2\%). The genotypes of all ninetyseven HCV nucleic acid positive patients were revealed by this kit. Although the kit used in this study was able to detect only genotypes $1 \mathrm{a}, 1 \mathrm{~b}, 2$ and $3 \mathrm{a}$, all the samples were identified suggesting that the common genotypes are those reported here. We cannot rule out the possibility of mix infection with genotypes which the kit is not designed to detect, though according to the literature, other genotypes in that area are very rare.

There are several reports regarding the distribution of different HCV genotypes in different parts of Iran. In a population-based study 116 samples from HCV RNA positive patients from different parts of Iran were analyzed using PCR-RFLP. The authors reported that $1 \mathrm{a}$, $3 \mathrm{a}$, and $1 \mathrm{~b}$ were the predominant genotypes with an overall prevalence rate of $61.2 \%, 25 \%$ and $13.8 \%$ respectively [9]. In a study in Fars province (Iran), during 2004-2005, among 188 subjects with HCV infection, $44.1 \%$ were genotype la, $42.0 \%$ genotype $3 \mathrm{a}$ and $13.8 \%$ genotype $1 \mathrm{~b}$ [10]. They used Nested-PCR and PCRRFLP for genotyping and stated that genotypes other than those reported could not be found in that area. In comparison with studies made in Iran's neighbor countries, it can be understood that the most common genotype in Kuwait, Iraq, and Saudi Arabia is type 4 [11]. However, genotype $1 \mathrm{~b}$ in Turkey in the western border of Iran and genotype 3a in Pakistan in the eastern border of Iran are more prevalent $[12,13]$. Although genotype 4 is found almost exclusively in Middle East and western countries [14], this genotype is very uncommon in Iran. From different studies conducted in different parts of Iran, it generally could be concluded that genotypes $1 \mathrm{a}$ and $3 \mathrm{a}$ are the most prevalent in Iran while $1 \mathrm{~b}$ and 2 are less frequent and other genotypes are rare $[9,15]$. A similarity has been reported between Iran and both Pakistan and India, in which genotype 3 is very prevalent and genotype 2 is rare [16,17]. It could be due to the high rate of immigration from these countries to Iran, especially when considering the fact that the prevalence of HCV infection in these countries is higher than in Iran. Genotypes 3a and 1a are more prevalent in intra-venous drug abusers (IVDU) in Europe and USA [18-20]. In the present study, 85 patients $(86.5 \%)$ were
IV drug abusers among whom HCV genotype $3 a$ and $1 \mathrm{a}$ were more prevalent. It seems that there is a high similarity between the pattern of genotype in IVDU in Europe, the United States and Iran.

\section{Conclusion}

In conclusion, our results are in accordance with other reports demonstrating the predominance of genotypes $3 \mathrm{a}$ and $1 \mathrm{a}$ and a very low frequency of genotype 2 in Iran which is different from Europe, USA and even some parts of Asia [11,21-24].

\section{Methods}

\section{Patients and study design}

This is a descriptive cross-sectional study. Patients who were suspected of hepatitis were referred to two large medical centers by specialists in Isfahan province (Iran) between March 2007 and April 2009. They were screened primarily for anti-HCV antibodies using a commercial ELISA kit. Those who were positive for anti-HCV antibodies were selected for HCV RNA detection using the RT-PCR technique. Out of 146 anti-HCV antibody positive patients, 97 were positive for $\mathrm{HCV}$ RNA. Patients who were positive for anti-HCV antibodies but were negative for HCV RNA were under treatment and were excluded. All samples from HCV RNA positive patients were selected for the study and were subjected to HCV genotype determination using commercial RT-PCR based kit. A waiver of consent was provided by the executive ethics committee of the medical center, as the samples used in this study were surplus to requirements following diagnostic investigations.

\section{Plasma samples}

Ten $\mathrm{ml}$ venous blood samples were collected from each patient referred to the laboratory. Blood samples were collected in tubes containing EDTA. Centrifuged and separated plasmas were immediately stored at $-80^{\circ} \mathrm{C}$. To avoid RNA degradation, aliquots were not thawed more than once prior to analysis.

\section{HCV RNA detection}

Plasma samples were tested for the presence of $\mathrm{HCV}$ nucleic acid using, with general primers, the conventional RT-PCR commercial kit (Qiagen, Germany) which is able to detect all different HCV genotypes. Tests were conducted according to manufacturer's recommendations. Briefly they were as follows: $50 \mu \mathrm{l}$ plasma was added to $5.6 \mu \mathrm{l}$ RNA carrier and $560 \mu \mathrm{l}$ of lysis buffer, incubated at room temperature for $10 \mathrm{~min}$ before having $560 \mu \mathrm{l}$ of ethanol (96-100\%) added. $630 \mu \mathrm{l}$ of the solution was transferred to the Minispin column, centrifuged at $6000 \mathrm{~g}$ for $1 \mathrm{~min}$ and then the spin column was placed into a clean $2 \mathrm{ml}$ collection tube, the 
tube containing the filtrate being discarded. Subsequently $500 \mu \mathrm{l}$ of washing buffer was added and centrifuged at $6000 \mathrm{~g}$ for $1 \mathrm{~min}$, again the tube containing the filtrate was discarded. $500 \mu \mathrm{l}$ of elution buffer was added and centrifuged at full speed for 3 min. Finally, $60 \mu \mathrm{l}$ of dissolving buffer was added to the last spin column to collect the RNA. Small aliquots of isolated RNA were tested to assess the quality and quantity of RNA using a spectrophotometer (Eppendorf, Germany). Two $\mu \mathrm{g}$ of RNA was reverse-transcribed into cDNA using a master mix of 5XRT mix, M-MLV reverse-transcribe enzyme, RNAse inhibitor, dNTPs and $\mathrm{ddH}_{2} \mathrm{O}$ and then placed on a thermal cycler (Eppendorf, Germany) at $37^{\circ} \mathrm{C}$ for $30 \mathrm{~min}$. Five $\mu \mathrm{l}$ of cDNA was subjected to PCR amplifications using general primers included in the kit, which is able to amplify all different genotypes of HCV. The PCR program was as follows: initial denaturation at $95^{\circ}$ $\mathrm{C}$ for $5 \mathrm{~min}$, and then $45 \mathrm{cycles}$ at $95^{\circ} \mathrm{C}$ for $30 \mathrm{sec}, 57^{\circ} \mathrm{C}$ for $15 \mathrm{sec}, 72^{\circ} \mathrm{C}$ for $30 \mathrm{sec}$ and a final extension at $72^{\circ} \mathrm{C}$ for $5 \mathrm{~min}$. PCR products were subjected to electrophoreses and separation on $2 \%$ agarose gel, being visualized under UV light after ethidium bromide staining.

\section{HCV genotyping}

Samples positive for HCV RNA were subjected to $\mathrm{HCV}$ genotyping using a commercial kit (Sacace, Italy) according to manufacturer's recommendations. This kit is designed for the detection of genotypes $1 \mathrm{a}, 1 \mathrm{~b}, 2,3 \mathrm{a}$ (most common HCV genotypes in Iran) by generating different size PCR products. The specificity and sensitivity of the kit are $100 \%$ and 1000 viral particles per ml respectively according to the manufacturer. For each patient two sets of PCR amplifications were carried out in two separate tubes containing primers for either genotypes $1 \mathrm{a}+1 \mathrm{~b}$ or genotypes $2+3 \mathrm{a}$. Five $\mu \mathrm{l}$ of cDNA was subjected to PCR amplifications using two sets of mixed primers included in the kit. The PCR program was as follows: initial denaturation at $95^{\circ} \mathrm{C}$ for $5 \mathrm{~min}$, and then 42 cycles of $95^{\circ} \mathrm{C}$ for $1 \mathrm{~min}, 68^{\circ} \mathrm{C}$ for $1 \mathrm{~min}, 72^{\circ} \mathrm{C}$ for 1 min and a final extension at $72^{\circ} \mathrm{C}$ for $10 \mathrm{~min}$. Genotype 1a generates a 338 bp PCR product, 1b 395 bp, 2286 bp and 3a 227 bp. PCR products were electrophoresed, separated by $2 \%$ agarose gel and visualized under UV light after ethidium bromide staining.

\footnotetext{
Acknowledgements

This study was supported in part by Mahdieh Diagnostic Centre Charity, Isfahan, Iran. Authors are grateful of University of Isfahan for its support. Authors would like to thank Mr. MG Copeland for revision of the manuscript.

\section{Author details}

'Department of Biology, Faculty of Sciences, University of Isfahan, Isfahan, 81746-73695, IR, IRAN. Department of Immunology, Medical School, Isfahan University of Medical Sciences, Hezar Jerib Street, Isfahan, 81746-73695, IR, IRAN. ${ }^{3}$ Department of Biology, Faculty of Sciences, University of Isfahan, Hezar Jerib Street, Isfahan, 81746-73695, IR, IRAN. ${ }^{4}$ Department of Pathology,
}

Medical School, Isfahan University of Medical Sciences, Hezar Jerib Street, Isfahan, 81746-73695, IR, IRAN.

\section{Authors' contributions}

$\mathrm{SHZ}$ supervised the experiments and contributed to data analysis and the preparation of the manuscript. MTK performed all the experiments and contributed to data analysis. MA contributed to data analysis and the preparation of the manuscript. All authors read and approved the final manuscript.

\section{Competing interests}

The authors declare that they have no competing interests.

Received: 24 November 2009 Accepted: 24 March 2010

Published: 24 March 2010

\section{References}

1. Choo QL, Kuo G, Weiner AJ, Overby LR, Bradley DW, Houghton M: Isolation of a cDNA clone derived from a blood-borne non-A, non-B viral hepatitis genome. Science 1989, 244:359-362.

2. Freeman AJ, Dore GJ, Law MG, Thorpe M, Von Overbeck J, Lloyd AR, Marinos G, Kaldor JM: Estimating progression to cirrhosis in chronic hepatitis C virus infection. Hepatology 2001, 34:809-816.

3. EASL International Consensus Conference on Hepatitis C. Paris, 26-28, February 1999, Consensus Statement. European Association for the Study of the Liver. J Hepatol 1999, 30:956-961.

4. National Institutes of Health Consensus Development Conference Panel statement: management of hepatitis C. Hepatology 1997, 26:25-10S.

5. McHutchison JG, Gordon SC, Schiff ER, Shiffman ML, Lee WM, Rustgi VK, Goodman ZD, Ling MH, Cort S, Albrecht JK: Interferon alfa-2b alone or in combination with ribavirin as initial treatment for chronic hepatitis $C$. Hepatitis Interventional Therapy Group. N Engl J Med 1998, 339:1485-1492.

6. Krekulova L, Rehak V, Wakil AE, Harris E, Riley LW: Nested restriction sitespecific PCR to detect and type hepatitis $C$ virus (HCV): a rapid method to distinguish HCV subtype $1 \mathrm{~b}$ from other genotypes. J Clin Microbiol 2001, 39:1774-1780.

7. Ross RS, Viazov S, Wolters B, Roggendorf M: Towards a better resolution of hepatitis C virus variants: CLIP sequencing of an HCV core fragment and automated assignment of genotypes and subtypes. J Virol Methods 2008, 148:25-33

8. Ramia S, Eid-Fares J: Distribution of hepatitis C virus genotypes in the Middle East. Int J Infect Dis 2006, 10:272-277.

9. Amini S MFMAM, Alavian SM, Joulaie M, Ahmadipour MH: Distribution of hepatitis C Virus Genotypes in Iran: a Population-Based Study. Hepatitis Monthly 2009, 9:95-102.

10. Davarpanah MA SM, Bagheri Lankarani K, Mehrabani D, BehzadBehbahani A, Serati A, Ardebili M, Yousef M, Khademolhosseini F, KeyvaniAmineh H: Hepatitis C Virus Genotype distribution is Shiraz, Southern Iran. Hepatitis Monthly 2009, 9:122-127.

11. Simmonds P, Holmes EC, Cha TA, Chan SW, MCOmish F, Irvine B, Beall E, Yap PL, Kolberg J, Urdea MS: Classification of hepatitis C virus into six major genotypes and a series of subtypes by phylogenetic analysis of the NS-5 region. J Gen Virol 1993, 74(Pt 11):2391-2399.

12. Abacioglu YH, Davidson F, Tuncer S, Yap PL, Ustacelebi S, Yulug N, Simmonds P: The distribution of hepatitis $C$ virus genotypes in Turkish patients. J Viral Hepat 1995, 2:297-301.

13. Shah HA, Jafri W, Malik I, Prescott L, Simmonds P: Hepatitis C virus (HCV) genotypes and chronic liver disease in Pakistan. $J$ Gastroenterol Hepatol 1997, 12:758-761

14. Mellor J, Holmes EC, Jarvis LM, Yap PL, Simmonds P: Investigation of the pattern of hepatitis $C$ virus sequence diversity in different geographical regions: implications for virus classification. The International HCV Collaborative Study Group. J Gen Virol 1995, 76(Pt 10):2493-2507.

15. Zali MR, Mayumi M, Raoufi M, Nowroozi A: Hepatitis C virus genotypes in the Islamic Republic of Iran: a preliminary study. East Mediterr Health $J$ 2000, 6:372-377.

16. Khokhar $\mathrm{N}$, Asif $\mathrm{N}$, Khokhar OS: Serotype 3 is most common hepatitis $\mathrm{C}$ serotype in Pakistan: however, significant numbers are untypeable. Hepatology 2003, 38:270-271. 
17. Chowdhury A, Santra A, Chaudhuri S, Dhali GK, Maity SG, Naik TN, Bhattacharya SK, Mazumder DN: Hepatitis C virus infection in the general population: a community-based study in West Bengal, India. Hepatology 2003, 37:802-809.

18. McOmish F, Chan SW, Dow BC, Gillon J, Frame WD, Crawford RJ, Yap PL, Follett EA, Simmonds $P$ : Detection of three types of hepatitis $C$ virus in blood donors: investigation of type-specific differences in serologic reactivity and rate of alanine aminotransferase abnormalities. Transfusion 1993, 33:7-13.

19. Pistello M, Maggi F, Vatteroni L, Cecconi N, Panicucci F, Bresci GP, Gambardella L, Taddei M, Bionda A, Tuoni M, et al: Prevalence of hepatitis C virus genotypes in Italy. J Clin Microbiol 1994, 32:232-234.

20. Pawlotsky JM, Tsakiris L, Roudot-Thoraval F, Pellet C, Stuyver L, Duval J, Dhumeaux D: Relationship between hepatitis $C$ virus genotypes and sources of infection in patients with chronic hepatitis C. J Infect Dis 1995, 171:1607-1610.

21. McOmish F, Yap PL, Dow BC, Follett EA, Seed C, Keller AJ, Cobain TJ, Krusius T, Kolho E, Naukkarinen R, et al: Geographical distribution of hepatitis $C$ virus genotypes in blood donors: an international collaborative survey. J Clin Microbiol 1994, 32:884-892.

22. Bukh J, Purcell RH, Miller RH: At least 12 genotypes of hepatitis $\mathrm{C}$ virus predicted by sequence analysis of the putative $\mathrm{E} 1$ gene of isolates collected worldwide. Proc Natl Acad Sci USA 1993, 90:8234-8238.

23. Simmonds P: Variability of hepatitis C virus. Hepatology 1995, 21:570-583.

24. Viazov S, Zibert A, Ramakrishnan K, Widell A, Cavicchini A, Schreier E, Roggendorf M: Typing of hepatitis $C$ virus isolates by DNA enzyme immunoassay. J Virol Methods 1994, 48:81-91.

doi:10.1186/1743-422X-7-69

Cite this article as: Zarkesh-Esfahani et al.: Hepatitis C virus genotype frequency in Isfahan province of Iran: a descriptive cross-sectional study. Virology Journal 2010 7:69.

\section{Submit your next manuscript to BioMed Central and take full advantage of:}

- Convenient online submission

- Thorough peer review

- No space constraints or color figure charges

- Immediate publication on acceptance

- Inclusion in PubMed, CAS, Scopus and Google Scholar

- Research which is freely available for redistribution

Submit your manuscript at www.biomedcentral.com/submit 